\title{
Lewis acid catalysts: a potential exploitation for zinc and nickel phytoextraction
}

\author{
G. Losfeld ${ }^{1,2}$, P. Vidal de la Blache ${ }^{1,2}$, V. Escande ${ }^{3}$ \& C. Grison ${ }^{1}$ \\ ${ }^{1}$ Centre d'Ecologie Fonctionnelle et Evolutive, UMR CNRS 5175, France \\ ${ }^{2}$ Ecole Polytechnique, Palaiseau, France \\ ${ }^{3}$ Institut de Chimie des Substances Naturelles, UPR 2301, France
}

\begin{abstract}
We explore the outlines of an innovative method, which is the chemical recovery of heavy metal contaminated biomass produced through phytoextraction technologies. Taking advantage of the adaptive capacity of certain plants to hyperaccumulate metallic cations in their aerial parts, the design of this program is based on the direct use of metal derived from plants as supported 'Lewis acid' catalysts in organic chemistry. These original polymetallic systems serve as heterogeneous catalysts in synthetic transformations allowing access to molecules with high added value: results for Friedel-Crafts acylations and alkylations are presented here. The acetylation of anisole and benzylation of toluene are considered in more details. The design of processes aims to reduce environmental impacts at each step and the method is adapted to the principles of Green Chemistry. It can constitute an incentive for the economic development of phytoextraction to remediate trace metal contamination; and it is also a concrete solution to the criticality of non-renewable mineral materials.

Keywords: heterogeneous catalysis, green and sustainable chemistry, trace metals, hyperaccumulator plants, biomass, phytoextraction.
\end{abstract}

\section{Introduction}

Intensive mining and industrial activities using heavy metals be a serious source of soil pollution: tailings often present high metal concentrations and remain in place when exploitations stop. Estimations for metal releases in the environment for the period 1950-2000 amount to 22,000t for cadmium, 939,000t for copper, $783,000 t$ for lead and $1,350,000 t$ for zinc [1]. Heavy metals are not 
biodegradable and tend to get increasingly concentrated in living organisms along the food chain in the bioaccumulation process. Thus any release of heavy metals in the environment may have serious effects that cannot be underestimated. Local soil pollution may cause a decrease in vegetation cover or total absence of vegetation with possible impacts on upper trophic levels. Heavy metal pollution also directly affects the development potential of the contaminated areas and endangers livelihoods. Contaminated dust from brownfields may be blown by winds and soil washing by rainfalls may also cause the presence of heavy metals in food crops or drinking water, with potential health issues as a direct consequence.

In spite of their toxicity heavy metals can also exert a selective pressure on living organisms: metal tolerant plants are those able to grow on metal contaminated soils while metal hyperaccumulator plants can extract, transport and concentrate metals from soil into their roots and aboveground shoots. By definition, a hyperaccumulator can accumulate at least $100 \mathrm{mg} \cdot \mathrm{kg}^{-1} \mathrm{Cd}$ or As or $1,000 \mathrm{mg} \cdot \mathrm{kg}^{-1} \mathrm{Co}, \mathrm{Cu}, \mathrm{Cr}, \mathrm{Pb}$ or $\mathrm{Ni}$ or $10,000 \mathrm{mg} \cdot \mathrm{kg}^{-1} \mathrm{Mn}$ or $\mathrm{Zn}$ [2]. Since the discovery of the first nickel hyperaccumulator in New Caledonia [3] various metal hyperaccumulators have been studied: forty-eight Alyssum taxa widely spread throughout the world have been found to hyperaccumulate nickel [2]. In New Caledonia, numerous species such as Psychotria douarrei and Geissois pruinosa are known to hyperaccumulate nickel and three species of Grevillea are known as manganese hyperaccumulators [4]. In the South of France (SaintLaurent-le-Minier) the Ganges ecotype of Thlaspi caerulescens was found on brownfields where mining recently stopped: it accumulates zinc at levels above $10,000 \mathrm{mg} \cdot \mathrm{kg}^{-1}$ as well as cadmium [5]. This unique biodiversity could be a tool for the remediation of trace metals pollution and an alternative source of metals with high potential in organic synthesis. The results we present here show the possibilities of using contaminated biomass to produce Lewis acid catalysts used in Friedel-Crafts acylations and alkylations.

\section{Phytoremediation and the issue of the contaminated biomass}

\subsection{Remediation of heavy metal pollution}

The conventional method to remediate heavy metal pollution is excavation followed by burial at a waste site for an estimated cost of $\$ 400,000$ per treated hectare [6]. At this price, both for mining companies and for the environment, phytoremediation then appears as a cost-effective and sustainable method to reclaim metal polluted soils [6]. It is also aesthetically more pleasing and shows better public acceptance [1]. Four different phytoremediation methods are usually considered: phytoextraction, rhizofiltration, phytostabilisation and phytovolatilisation [7] but the combination of phytoextraction and phytostabilisation showed the greatest potential [8-10]. Phytostabilisation 
consists of covering soils with plants able to withstand pollution: the development of the plants' root system contains pollution and prevents soils erosion. Phytoextraction is when pollutants are extracted from soils and stored by plants (in roots, shoots or both). Wide-scale development of phytoextraction requires agronomic skills: previous examples on nickel phytoextraction showed that it was possible to achieve yields good enough to foresee commercial applications [11-13]. Recent studies in France showed that legume species Anthyllis vulneraria could also perform phytoextraction and prove a useful tool to improve soil fertility in phytoextraction schemes [14, 15]. However phytoextraction only shifts the heavy metal contamination issue from soil to biomass and phytoextraction per se is not an integrated solution.

\subsection{From contaminated soils to contaminated biomass}

Currently, the main outlet for metal contaminated biomass produced in phytoextraction is an alternative metal production process called "phytomining" $[16,17]$ metal hyperaccumulator plants are considered as a "bio-ore" and the commercial value of the metals obtained could balance the costs involved in the development of phytoextraction. As leaves need to be burned to ashes in the process, a possible recovery of energy may also be taken into account: expected returns in the case of nickel including metal and energy production are estimated to $\$ 1,311$ per hectare [16]. The alternative we propose, which is to use the contaminated biomass to produce Lewis acid catalysts is conceptually very different from phytomining.

\subsubsection{Treatment applied to the biomass}

We recently reported preliminary results in two international patents $[18,19]$. The challenge we faced was to develop a clean methodology to recover metals from biomass. One aim was to avoid the use of hazardous substances such as organic solvents or separation agents. The selection of conditions was guided towards a simple, low-cost and efficient process which is also compliant with industrial requirements.

In a first step, a thermal treatment is applied to the harvested biomass at $400^{\circ} \mathrm{C}$ in order to destroy organic matter. In a second step, the ashes obtained are treated with $1 \mathrm{M}$ hydrochloric acid to finish the destruction of the remaining organic compounds and to convert metallic cations into metal chlorides. The reaction mixture was stirred for $2 \mathrm{~h}$ at $60^{\circ} \mathrm{C}$, and then filtered on celite. The resulting aqueous solution, composed of different metal chlorides, is then concentrated under vacuum and dry residues stored in a stove at $90^{\circ} \mathrm{C}$ until the next laboratory period. Inductively Coupled Plasma - Mass Spectrometry (ICPMS) was used to determine the composition of the various extracts obtained (AETE Platform - Hydrosciences, Montpellier - France). Results are summarised in Table 1. 
Table 1: Composition of the different plant extract obtained with our process.

\begin{tabular}{|c|c|c|c|c|c|}
\hline Catalyst & Mg & Al & $\mathbf{C a}$ & Mn & $\mathrm{Fe}$ \\
\hline \multicolumn{6}{|l|}{ T. caerulescens extract } \\
\hline Concentration (ppm) & 15,921 & 10,904 & 100,641 & 594 & 48,322 \\
\hline \multicolumn{6}{|l|}{ A. vulneraria extract } \\
\hline Concentration (ppm) & 35,876 & 6,015 & 668,579 & 862 & 14,888 \\
\hline \multicolumn{6}{|l|}{$\begin{array}{c}\text { T. caerulescens }+A . \\
\text { vulneraria extract }\end{array}$} \\
\hline Concentration (ppm) & 28,202 & 14,878 & 134,925 & 936 & 27,275 \\
\hline \multicolumn{6}{|l|}{$P$. douarrei extract } \\
\hline \multirow[t]{2}{*}{ Concentration (ppm) } & 20,768 & 5,419 & 96,731 & 1,402 & 5,570 \\
\hline & $\mathbf{N i}$ & $\mathrm{Cu}$ & Zn & Cd & $\mathbf{P b}$ \\
\hline \multicolumn{6}{|l|}{ T. caerulescens extract } \\
\hline \multicolumn{6}{|l|}{ A. vulneraria extract } \\
\hline Concentration (ppm) & 2,734 & 2,460 & 154,202 & 533 & 11,700 \\
\hline \multicolumn{6}{|l|}{$\begin{array}{c}\text { T. caerulescens }+A . \\
\text { vulneraria } \text { extract }\end{array}$} \\
\hline Concentration (ppm) & 2,985 & 523 & 91,232 & 4,845 & 29,249 \\
\hline \multicolumn{6}{|l|}{ P. douarrei extract } \\
\hline Concentration (ppm) & 80,153 & 299 & 7,902 & 80 & 703 \\
\hline
\end{tabular}

\subsubsection{Degree of oxidation}

In our process, metallic species are obtained directly at the targeted degree of oxidation which is $\mathrm{Ni}(\mathrm{II})$ in $P$. douarrei and $G$. pruinosa and $\mathrm{Zn}$ (II) in $T$. caerulescens and $A$. vulneraria. In phytomining a reduction needs to take place to turn metallic cations into metals; $\mathrm{Ni}(\mathrm{II})$ for example into $\mathrm{Ni}(0)$. The only thing we need to take into account is which anionic species goes along with the metallic cation of interest: in $T$. caerulescens studies showed that $\mathrm{Zn}$ (II) was probably transported as a histidine chelate [20] while $\mathrm{Zn}$ (II) is stored in cell vacuoles as a malate chelate [21]. In this case we only need to turn zinc-malate complexes into zinc chloride.

\subsubsection{Metal concentration in the biomass and purification issues}

Phytomining is clearly targeting low-grade ores where traditional mining would not be cost-effective $[16,17]$ however the promoted end use also requires large quantities of metals. This is not necessarily the case for Lewis acid catalysis: according to the usual definition, a catalyst should be added in small quantities (compared to other reagents) to increase the reaction kinetics but without being consumed in the reaction. Thus as a general rule, $2 \%$ to $5 \%$ of metal are enough 
to convert 1 mole of substrate. Another reason for that is because we expect to benefit from the natural polymetallic composition of the biomass obtained from metal hyperaccumulators: in the case of $T$. caerulescens levels of $\mathrm{Zn}$ (II) and $\mathrm{Fe}(\mathrm{III})$ could be a problem to produce pure $\mathrm{Zn}(0)$ or $\mathrm{Fe}(0)$ while we may expect interesting properties from the combination of $\mathrm{ZnCl}_{2}$ and $\mathrm{FeCl}_{3}$. Purification steps are not mandatory in our process and when required, partial purifications only may be considered to select most active species.

\section{Use of the contaminated biomass in "Lewis acid" catalysis}

\subsection{Heterogeneous catalysis and green chemistry}

The green revolution in organic chemistry, initiated in the $1980 \mathrm{~s}$, is just starting to gain momentum today. Green chemistry wishes to contribute efficiently to the reduction of waste by developing new processes involving sustainable reuse and extension of the lifetime of reagents, reduction of quantities and the substitution and diversification of raw materials used in the discipline. Spurred by new regulations like REACH (Registration, Evaluation and Authorisation of CHemicals) in Europe and networks such as the Green and Sustainable Chemistry Network (GSCN), deep changes are coming concerning new technologies and processes more respectful of the environment.

The use of catalysis was established as the $9^{\text {th }}$ of the twelve principles of green chemistry [22] and it is sometimes referred to catalysis as the "foundational pillar" of green chemistry [23]. Heterogeneous catalysis presents itself as the latest improvement: it proved a pertinent solution to all the problems it tackles. The apparition of zeolites, solid acid catalysts that are often alumina silicate based, gave a new impetus to heterogeneous catalysis at the end of the 1980s [24]. The advantages of heterogeneous catalysis are numerous: small quantities in reactions, regeneration, allows the softening of experimental conditions, increased selectivity, possibility to work in fixed beds for the industry, capacity to use far less organic solvents. Seldom used by the industry up to now, market perspectives are vast for the years to come, as shows the abundant literature on the subject.

However, zeolites also show certain limits: even if these solid catalysts can be 'tailored' for a specific reaction, they are often doped with hazardous products (expensive rare earth or metals). These catalysts remain costly and pollutant, with an energy-extensive use: zeolites require long and high-temperature thermal activations. New cheaper and less pollutant catalysts are therefore studied. Supported metal halides (in particular metal chlorides supported on silica and clays such as montmorillonite) are very promising [24]. The processes we developed take these considerations into account as much as possible to produce efficient 'green' catalysts. 


\subsection{Friedel-Crafts acylations}

Friedel-Crafts acylations, first described in the late $19^{\text {th }}$ century, consists of the production of an aromatic ketone by adding an acyl component in the presence of a catalyst. Since, it has been one of the pillars of organic chemistry both for the industry and for the academic world. Aromatic ketones constitute fundamental intermediates for the fragrance, flavour, dye, agrochemical and pharmaceutical industries [25].

During most of the last century, Friedel-Crafts acylations were done in homogeneous phase and in more than stoichiometric quantity of strong Lewis acids $\left(\mathrm{AlCl}_{3}, \mathrm{FeCl}_{3}\right)$ as a 'catalyst' and with acyl chlorides or anhydride acids as reagents. The need for several equivalents of Lewis acid can be explained by the fact that the synthesized ketone 'consumes' one equivalent Lewis acid, as it is a far better Lewis base than the reagent. For example, the produced ketone is a Lewis base a hundred times stronger than ethanoyl chloride when using $\mathrm{FeCl}_{3}$ in the acetylation of anisole [26]. The formed metallic residues must be destroyed, which implies an acid (or basic) treatment before returning to an organic solvent. The use of heterogeneous catalysis allows overcoming this step for future reactions. It also allows considering a recycling of the catalytic system by a simple filtration and thermal activation for ulterior use.

The acetylation of anisole (figure 1) in heterogeneous catalysis is a witness of the recent evolution of chemistry towards new, more environmentally friendly processes. Described for the first time in homogeneous catalysis in 1932 (Spagnol et al. [27]), the synthesis of 4-methoxy-acetophenone is an important step in the chemical industry for the production of paint additives, precursors for resins, photoinitiators, pharmaceuticals and ester fragrances [28]. It is a significant reaction as it is one the first electrophilic aromatic substitution achieved on an industrial scale in heterogeneous catalysis over zeolites [27]. Since, the reaction has been extensively studied $[24,25,28]$ and appears as a very interesting model to test the efficiency of 'green' Lewis acid supported catalysts.

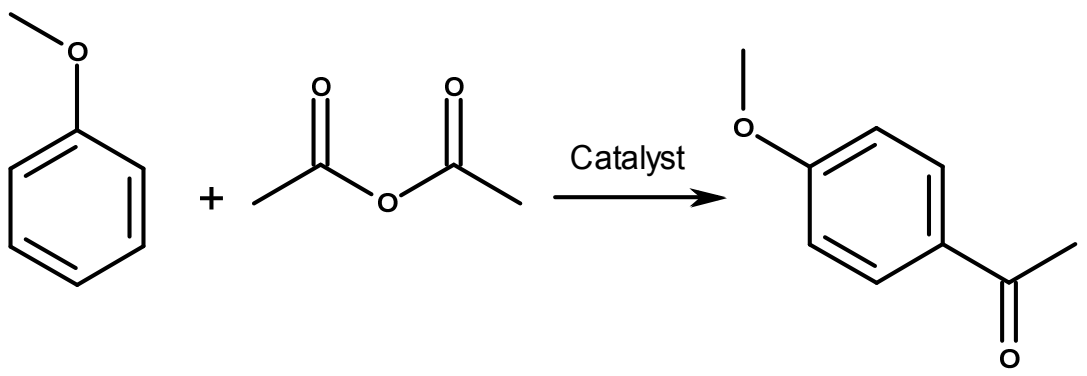

Figure 1: Acetylation of anisole. 


\subsubsection{Results for the acetylation of anisole}

Acetylation of anisole was investigated in heterogeneous catalysis using raw (not purified) plant extracts drawn from $T$. caerulescens (containing majorly $\mathrm{ZnCl}_{2}$ ) or $P$. douarrei (containing majorly $\mathrm{NiCl}_{2}$ ) and commercial $\mathrm{ZnCl}_{2}$ or $\mathrm{NiCl}_{2}$ supported on montmorillonite K10. Results obtained are summarised in Table 2.

Table 2: $\quad$ Yields in acetylation of anisole.

\begin{tabular}{|c|c|c|c|c|}
\hline Catalyst & $\begin{array}{c}\mathrm{ZnCl2} \\
\text { or } \\
\mathrm{NiCl} 2 \\
\text { eq }\end{array}$ & $\begin{array}{c}\mathrm{ZnCl}_{2}+ \\
\mathrm{FeCl}_{3}+ \\
\mathrm{AlCl}_{3}+ \\
\mathrm{NiCl}_{2} \mathbf{e q}\end{array}$ & $6 h$ & $15 h$ \\
\hline $\mathrm{ZnCl}_{2}$ in homogeneous phase $(1 \mathrm{~g})$ & 2.6 & 2.6 & $100 \%$ & $100 \%$ \\
\hline $\mathrm{ZnCl}_{2}$ on $\mathrm{K}-10(1 \mathrm{~g} / 1.5 \mathrm{~g})$ & 2.6 & 2.6 & $100 \%$ & $100 \%$ \\
\hline T. caerulescens on $\mathrm{K}-10(1 \mathrm{~g} / 1.5 \mathrm{~g})$ & 0.85 & 1.24 & $100 \%$ & $100 \%$ \\
\hline $\mathrm{NiCl}_{2}$ in homogeneous phase $(1 \mathrm{~g})$ & 2.8 & 2.8 & $44 \%$ & $81 \%$ \\
\hline $\mathrm{NiCl}_{2}$ on $\mathrm{K}-10(1 \mathrm{~g} / 1.5 \mathrm{~g})$ & 2.8 & 2.8 & $78 \%$ & $79 \%$ \\
\hline P. douarrei on K-10 (1g/1.5g) & 0.85 & 1.1 & $85 \%$ & $84 \%$ \\
\hline
\end{tabular}

In heterogeneous phase the para/ortho ratio rises dramatically, which is an effect mentioned in the literature [27] that we also observed. This is due to a rearrangement of other products towards the more thermodynamically stable para compound: it is positive as it avoids purification issues. $\mathrm{ZnCl}_{2}$ in a homogeneous reaction is known as a modest catalyst which is why $\mathrm{AlCl}_{3}$ and $\mathrm{FeCl}_{3}$ are preferred industrially. However we succeeded in obtaining good yields: the difficulties encountered while dehydrating $\mathrm{ZnCl}_{2}$ (rapid caking after dehydration) might explain why some $\mathrm{ZnCl}_{2}$ may not enter the liquid organic phase. These difficulties to manipulate $\mathrm{ZnCl}_{2}$ justify ipso facto supporting it on montmorillonite or silica.

The reactions carried out using raw catalysts drawn from $T$. caerulescens show that the product can be obtained quantitatively when there are more than 2 equivalents present in the solid catalyst. Moreover, the raw catalyst shows results similar to $\mathrm{ZnCl}_{2}$ with about twice less active species, confirming the potential of these green, polymetallic catalysts.

The other interesting results concern 'green' catalysts containing $\mathrm{NiCl}_{2}$, which is an unusual Lewis acid for this reaction (to our knowledge, its use has never been reported). Entry 8 shows that raw catalysts drawn from $P$. douarrei show lower but interesting yields (considering the fact that it is seldom used in this reaction) when compared to those of catalysts drawn from $T$. caerulescens. Moreover, yields are higher for 'green' poly-metallic catalysts than they are for commercial $\mathrm{NiCl}_{2}$ catalysts even with about two times less equivalent active species. This is an important result for this reaction but also on a more theoretical level: this shows the advantage of polymetallic catalytic systems over monometallic catalysts, a result presented in Corma and Garcia [24]. 


\subsubsection{Preparation of 4-methoxy-acetophenone}

In heterogeneous catalysis, the catalyst $(1 \mathrm{~g})$ was dried prior to the reaction and supported on montmorillonite $\mathrm{K} 10(1,5 \mathrm{~g})$ in a typical procedure adapted from Gupta et al. [29] Acetic anhydride $(0.30 \mathrm{ml}$ or $0.15 \mathrm{ml})$ was added under $\mathrm{N}_{2}$, at $70^{\circ} \mathrm{C}$, to $3 \mathrm{ml}$ of anhydrous anisole with the supported catalyst. The mixture was stirred for 6 or 15 hours. The thick mixture is then filtered to recover the catalyst and diluted with dichloromethane $(20 \mathrm{ml})$. An internal standard (nitrobenzene, respectively $0.32 \mathrm{ml}$ or $0.16 \mathrm{ml}$ ) was added to measure the progress of the reaction using Gas Chromatography - Mass Spectrometry (GC-MS).

An electronic impact ionization mode on a Varian Saturn 2000 ion trap instrument, interfaced with a Varian CP-3800 apparatus. The Varian CP-3800 was equipped with a 1079 split-splitless injector $\left(206^{\circ} \mathrm{C}\right)$ and a $30 \mathrm{~m} \mathrm{x} 0.25 \mathrm{~mm} \mathrm{x}$ $0.25 \mathrm{~m}$ film thickness ID WCOT CPSil-8CB fused silica capillary column (Chrompack $^{\circledR}$, Bergen op Zoom, The Netherlands), with helium as carrier gas $(1,5 \mathrm{~mL} / \mathrm{min})$, and programmed $4 \mathrm{~min}$ isothermal at $70^{\circ} \mathrm{C}$, then increasing from $70^{\circ} \mathrm{C}$ to $160^{\circ} \mathrm{C}$ at $5^{\circ} \mathrm{C} / \mathrm{min}$ and finally from $160^{\circ} \mathrm{C}$ to $190^{\circ} \mathrm{C}$ at $15^{\circ} \mathrm{C} / \mathrm{min}$. Mass spectra were recorded in electronic impact (EI) at $70 \mathrm{eV}$, and identified by comparison with data of the NIST 98 software library (Varian, Palo Alto, CA, USA) and by comparison of the retention time of the standard compounds.

\subsection{Friedel-Crafts alkylations}

The first electrophilic aromatic substitution was discovered 134 years ago by Friedel and Crafts: it was the reaction between benzene and 1-chloropentane and was catalyzed by aluminium chloride [30]. The last step of the original process involved a workup implying neutralization, concomitant generation of water soluble aluminium salts and extraction to separate organic compounds from salts: as in the case of acylation, the catalyst was destroyed in this final step and large amounts of solvents were required. Today Friedel-Crafts alkylation remains the best pathway to produce substituted aromatic compounds and it is still widely used at the laboratory scale as well as at the industrial scale to produce fine chemicals or synthesis intermediates [31]. The synthesis of new compounds usually required new stronger catalysts including various metal halides and triflates: chemical production was thus far from sustainable and new catalysts were usually difficult to handle with corrosion issues in particular. These considerations led to the development of a new branch of research that aims to find new stable and fully recyclable catalysts, such as solid Lewis acids $[32,33]$. Latest reviews mention zeolites [34], clays [35], metal oxides [36] and supported reagents [31] but clay and clay-supported catalysts may be the most versatile catalysts with the widest range of possible uses [35].

\subsubsection{Use of supported plant extracts as benzylation catalysts}

Benzylation of aromatic compounds by benzyl chloride is a widely studied Friedel-Crafts alkylation for its products but also as a model for catalysis [37, 38]. We chose to adapt the process described in Van den Eynde et al. [38] to study toluene benzylation (Figure 2). Our results are summarised in Table 3. 


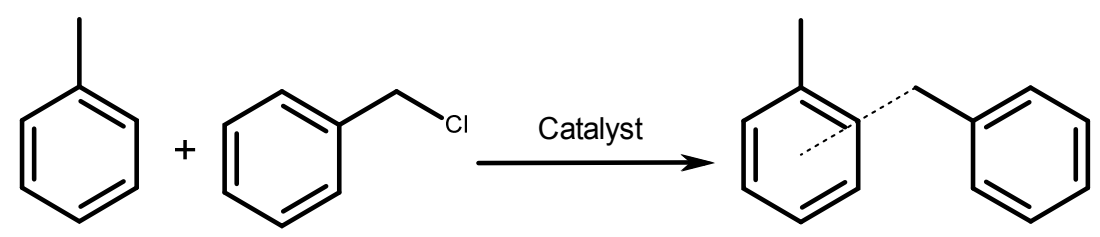

Figure 2: $\quad$ Toluene benzylation using benzyl chloride.

Table 3 shows how metal chlorides concentrations in plant extracts translate into equivalent metal chloride in the reaction conditions used. As regards zinc hyperaccumulators, they work better than commercial zinc chloride as a lesser quantity of Lewis acid gave the same yield. It is illustrated with the mix of $A$. vulneraria and $T$. caerulescens. The case of $P$. douarrei and $G$. pruinosa is different as $\mathrm{NiCl}_{2}$ is the main Lewis acid present: it is known to be a modest Lewis acid and it is only present at concentrations close to $80,000 \mathrm{ppm}$. However with 0.27 total equivalent metal chlorides it is still possible to obtain interesting yields in 3 hours. This result was not expected as no previous use of $\mathrm{NiCl}_{2}$ for this reaction had been reported so far. As it was the case for the acetylation of anisole, this shows the potential of $\mathrm{NiCl}_{2}$ in a polymetallic system and further investigations are required to fully determine the effects at hand. Ortho/para ratios do not significantly change: they are in accord with what is usually observed with montmorillonite supported metal halides. If we compare these results with those obtained with other catalysts, taking into account the simplicity of the process involved to produce the catalyst and the mild reaction conditions, it appears that plant extracts supported on montmorillonite K10 do well: Cseri et al. [37] reported total toluene benzylation in $3 \mathrm{~h}$ at $80^{\circ} \mathrm{C}$ using ion exchanged montmorillonite K10. More recently, Choudhary et al. [39] reported $80 \%$ yield in toluene benzylation using benzyl chloride in 25 minutes at $110^{\circ} \mathrm{C}$ using a In-Mg-hydrotalcite anionic clay.

Table 3: $\quad$ Toluene benzylation yields.

\begin{tabular}{cccc}
\hline Catalyst (0.15/0.20g) & $\begin{array}{c}\mathbf{Z n C l 2} \text { or } \\
\text { NiCl2 eq }\end{array}$ & $\begin{array}{c}\mathbf{Z n C l 2}+\text { FeCl3 + AlCl3 } \\
+ \text { NiCl2 eq }\end{array}$ & Yield (1h) \\
\hline None & - & - & $1 \%$ \\
$\mathrm{~K} 10(0.2 \mathrm{~g})$ & - & - & $10 \%$ \\
$\mathrm{ZnCl}_{2}$ on $\mathrm{K} 10$ & 0.62 & 0.62 & $100 \%$ \\
A. vulneraria $+T$. & 0.34 & 0.52 & $100 \%$ \\
caerulescens on $\mathrm{K} 10$ & & - & Yield (3h) \\
\hline- & - & 0.63 & $35 \%$ \\
\hline $\mathrm{NiCl}_{2}$ on $\mathrm{K} 10$ & 0.63 & 0.26 & $40 \%$ \\
$P$. douarrei on $\mathrm{K} 10$ & 0.21 & 0.27 & $50 \%$ \\
$G$. pruinosa on $\mathrm{K} 10$ & 0.19 & & \\
\hline
\end{tabular}




\subsubsection{Benzylation of toluene}

Our protocol is adapted from Van den Eynde et al. [38] who used commercial $\mathrm{ZnCl}_{2}$ supported on montmorillonite $\mathrm{K} 10$ as a catalyst for benzylation reactions. Plant extracts obtained through the process described in this article replaced commercial $\mathrm{ZnCl}_{2}$ and montmorillonite $\mathrm{K} 10$ was obtained from Alfa-Aesar. In a typical experiment, $200 \mathrm{mg}$ montmorillonite $\mathrm{K} 10$ were placed in a mortar and airdried. $150 \mathrm{mg}$ plant extract were then added and mixed with montmorillonite K10 using a pestle to obtain a homogeneous powder. This powder was then put in a dry round-bottom flask in which $2.11 \mathrm{~mL}(20 \mathrm{mmol})$ toluene and $0,115 \mathrm{~mL}$ ( $1 \mathrm{mmol})$ benzyl chloride were then added. The reaction mixture was left one hour at ambient temperature under magnetic stirring. The mixture is finally filtered, concentrated under reduced pressure and diluted in dichloromethane before GC-MS analyses with the conditions stated before.

\section{Conclusion and perspectives}

Phytoextraction is now considered as the most publicly accepted and sustainable method to remediate trace metals pollution. However to be fully applicable, this innovative technique needs strong incentives: more research needs to be carried out on the ecology of metal hyperaccumulators and agronomic techniques need to be developed, particularly in the South of France for zinc/cadmium phytoextraction. So far it appeared that phytomining could not give phytoextraction sufficient momentum to lead to a generalisation of the process to reclaim mining brownfields. The alternative we propose, which is to use metal hyperaccumulator plants species to produce Lewis acid catalysts used in organic synthesis could bring about change as it is probably more adapted to the state of metallic species present in plant tissues. The interest of the simple cost-effective process we presented here to produce efficient polymetallic Lewis acid catalysts is high for chemistry and particularly in a Green Chemistry approach. It could bring extra added value to the contaminated biomass produced. In terms of organic synthesis, perspectives include hydrochlorinations of alcohols, synthesis of aromatic heterocycle scaffolds, chiral cyclic structures, protections of alcohols and amines, aldolisations, metal catalysed rearrangements and other key syntheses of industrial and fine chemistry.

\section{References}

[1] O.V. Singh, S. Labana, G. Pandey, and R. Budhiraja, "Phytoremediation: an overview of metallic ion decontamination from soil," Applied Microbiology and Biotechnology, vol. 61, no. 5-6, pp. 405-412, 2003.

[2] R.D. Reeves and A.J.M. Baker, "Metal-accumulating plants," in Phytoremediation of Toxic Metals: Using Plants to Clean up the Environment. New-York: John Wiley and Sons, 2000.

[3] T. Jaffré, N. Perrier, F. Colin, J.-P. Ambrosia, J. Roseb, J.-Y. Bottero, "Nickel speciation in Sebertia acuminata, a plant growing on a lateritic soil 
of New Caledonia," Surface Geosciences (Pedology), vol. 336, no. 6, pp. 567-577, 1976.

[4] L. L'Huillier, T. Jaffré, and A. Wulff, Mines et environnement en NouvelleCalédonie: la revégétalisation des terrains miniers, 1 st ed., Institut Agronomique Calédonien, Ed. Nouméa, Nouvelle-Calédonie, 2010.

[5] F.-J. Zhao, R.E. Hamon, E. Lombi, M.J. McLaughlin, and S.P. McGrath, "Characteristics of cadmium uptake in two contrasting ecotypes of the hyperaccumulator Thlaspi caerulescens," Journal of Experimental botany, vol. 53, no. 368, pp. 535-543, 2002.

[6] D.J. Glass, "Economic Potential of Phytoremediation," in Phytoremediation of Toxic Metals: Using Plants to Clean up the Environment, B. Ensley and I. Raskin, Eds. New-York: John Wiley \& Sons, 1999.

[7] W.R. Berti and S.D. Cunningham, "Phytostabilization of metals," in Phytoremediation of Toxic Metals: Using Plants to Clean up the Environment, B. Ensley and I. Raskin, Eds. New-York: John Wiley \& Sons, 1999.

[8] V. Bert, P. Seuntjens, W. Dejonghe, S. Lacherez, H. Thi Thanh Thuy, B. Vandecasteele, "Phytoremediation as a management option for contaminated sediments in tidal marshes, flood control areas and dredged sediment landfill sites," Environmental Science and Pollution Research, vol. 16, pp. 745-764, 2009.

[9] M. Mench, J.P. Schwitzguébel, P. Schroeder, V. Bert, S. Gawronski, S. Gupta, "Assessment of successful experiments and limitations of phytotechnologies: contaminant uptake, detoxification and sequestration, and consequences for food safety," Environmental Science and Pollution Research, vol. 16, no. 7, pp. 876-900, 2009.

[10] M. Mench, N. Lepp, V. Bert, J.P. Schwitzguébel, S.W. Gawronski, P. Schröder, J. Vangronsveld, "Successes and limitations of phytotechnologies at field scale:outcomes, assessment and outlook from COST Action 859," Journal of Soils and Sediments, vol. 6, no. 10, pp. 1039-1070, 2010.

[11] R.L. Chaney, Y.-M. Li, E. Brewer, R. Roseberg, J.S Angle, A.J.M Baker, R.D. Reeves, J. Nelkin, "Development of a technology for commercial phytoextraction of nickel: economic and technical considerations," Plant and Soil, vol. 249, no. 1, pp. 107-115, 2003.

[12] R.L. Chaney, J.S. Angel, M.S. Mcintosh, and R.D. Reeves, "Using hyperaccumulator plants to phytoextract soil $\mathrm{Ni}$ and $\mathrm{Cd}$," Zum Naturforschung, vol. 60c, pp. 190-198, 2005.

[13] A. Bani, G. Echevarria, S. Sulçe, J.-L. Morel, and A. Mullai, "In-situ phytoextraction of $\mathrm{Ni}$ by a native population of Alyssum murale on an ultramafic site (Albania)," Plant and Soil, vol. 293, no. 1-2, pp. 79-89, 2007.

[14] H. Frérot, C. Lefèbvre, W. Gruber, C. Collin, A. Santos, J. Escarré, “Specific Interactions between Local Metallicolous Plants Improve the Phytostabilization of Mine Soils," Plant and Soil, vol. 282, no. 1-2, pp. 53-65, 2006.

[15] S. Mahieu, H. Frérot, C. Vidal, A. Galiana, K. Heulin, L. Maure, B. Brunel, C. Lefèbvre, J. Escarré, J.C Cleyet-Marel, "Anthyllis vulneraria Mesorhizobium metallidurans, an efficient symbiotic nitrogen fixing association able to grow in 
mine tailings highly contaminated by $\mathrm{Zn}, \mathrm{Pb}$ and Cd," Plant and Soil, vol. 342, no. 1-2, pp. 405-417, 2011.

[16] R.R. Brooks, M.F. Chambers, L.J. Nicks, and B.H. Robinson, "Phytomining," Trends in Plant Science, vol. 3, no. 9, pp. 359-362, 1998.

[17] R.L. Chaney, Y.-M. Li, S.L. Brown, F.A. Homer, M. Malik, J.S Angle, A.J.M. Baker, R.D. Reeves, M. Chin "Chapter 7. Improving Metal Hyperaccumulator Wild Plants to Develop Commercial Phytoextraction Systems," in Phytoremediation of Contaminated Soil and Water, Norman Terry, Ed.: CRC Press, 2000, p. 408.

[18] C. Grison and J. Escarré, "Utilisation de plantes accumulatrices d“éléments traces métalliques pour la mise en oeuvre de réactions chimiques," International Patent WO 2011/064462, Juin 3, 2011.

[19] C. Grison and J. Escarré, "Utilisation de plantes accumulatrices d“éléments traces métalliques pour la mise en oeuvre de réactions chimiques," International Patent WO 2011/064487, juin 3, 2011.

[20] N.S. Pence, P.B. Larsen, S.D. Ebbs, D.L.D Letham, M.M. Lasat, D.F Garvin, D. Eide, L.V Kochian "The molecular physiology of heavy metal transport in the $\mathrm{Zn} / \mathrm{Cd}$ hyperaccumulator Thlaspi caerulescens," Proceedings of the National Academy of Science of the United States of America, vol. 97, no. 9, pp. 4956-4960, April 2000.

[21] R.P. Tolrà, C. Poschenrieder, and J. Barceló, "Zinc hyperaccumulation in Thlaspi caerulescens. II. Influence on organic acids," Journal of Plant Nutrition, vol. 19, no. 12, pp. 1541 - 1550, 1996.

[22] P.T. Anastas and J.C. Warner, Green Chemistry: Theory and Practice. NewYork: Oxford University Press, 1998.

[23] P.T. Anastas, M.M. Kirchhoff, and T.C. Williamson, "Catalysis as a foundational pillar of green chemistry," Applied Catalysis A: General, vol. 221, no. 1-2, pp. 3-13, November 2001.

[24] A. Corma and H. Garcia, "Lewis acids: From Conventional Homogeneous to Green Homogeneous and Heterogeneous Catalysis," Chemical Reviews, vol. 103, no. 11, pp. 4307-4366, 2003.

[25] G. Sartori and R. Maggi, "Use of Solid Catalysts in Friedel-Crafts Acylation Reactions," Chemical Reviews, vol. 106, no. 3, pp. 1077-1104, February 2006.

[26] H. van Koningsveld, J.J. Scheele, and J.C. Jansen, "Structure of 4-tert-butyl2,6-dimethylacetophenone and comparison with its $\mathrm{FeCl} 3$ complex," Acta Crystallographica Section C, vol. 43, no. 2, pp. 175-177, February 1987.

[27] M. Spagnol, L. Gilbert, E. Benazzi, and C. Marcilly, "Procédé d'acylation d'éthers aromatiques.," Brevet Européen PCT/FR96/00717., 1998.

[28] U. Freese, F. Heinrich, and F. Roessner, "Acylation of aromatic compounds on H-Beta zeolites," Catalysis Today, vol. 49, no. 1-3, pp. 237-244, February 1999.

[29] R. Gupta, V. Kumar, M. Gupta, and S. Paul, "Silica supported zinc chloride catalyzed acetylation of amines, alcohols and phenols," Indian Journal of Chemistry, vol. 47, no. B, pp. 1739-1743, 2008.

[30] C. Friedel and J.M. Crafts, "Sur une nouvelle méthode générale de synthèse d'hydrocarbures, d'acétones.," Comptes rendus hebdomadaires des séances de l'Académie des sciences, vol. 84, pp. 1392-1395, 1877. 
[31] S. Dasgupta and B. Török, "Environmentally Benign Contemporary FriedelCrafts Chemistry by Solid Acids," Current Organic Synthesis, vol. 5, no. 4, pp. 321-342, November 2008.

[32] G.A. Olah, G.K.S. Prakash, and J. Sommer, Superacids. New-York: Wiley Interscience, 1985.

[33] Y. Izumi, K. Urabe, and A. Onaka, Zeolites, Clays, and Heteropoly Acids in Organic Reactions. Tokyo: Kodansha, 1992.

[34] S. Csicsery and M. Kiricsi, "Shape-Selective Catalysis," in Encyclopedia of Catalysis Vol.6, I.T. Horvath, Ed. New-York: Wiley, 2003, pp. 307-338.

[35] G. Nagendrappa, "Organic synthesis using clay and clay-supported catalysts," Applied Clay Science, vol. In Press, 2010.

[36] G.J. Hutchings, J.K. Bartley, C. Rhodes, S.H. Taylor, R.P.K. Wells, D.J. Willock "Metal Oxides," in Encyclopedia of Catalysis Vol 4., I.T. Horvath, Ed. New-York: Wiley, 2003, pp. 602-694.

[37] T. Cseri, S. Békássy, F. Figueras, and S. Rizner, "Benzylation of aromatics on ion-exchanged clays," Journal of Molecular Catalysis A: Chemical, vol. 98, no. 2, pp. 101-107, May 1995.

[38] J.-J. Van den Eynde, A. Mayence, and Y. van Haverbeke, "Ultrasound Promoted Benzylation of Arenes in The Presence of Zinc Chloride Mixed with a K10 Clay," Tetrahedron Letters, vol. 36, no. 18, pp. 3133-3136, 1995.

[39] V.R. Choudhary, R. Jhaa, and V.S. Narkhedea, "In-Mg-hydrotalcite anionic clay as catalyst or catalyst precursor for Friedel-Crafts type benzylation reactions," Journal of Molecular Catalysis A: Chemical, vol. 239, no. 1-2, pp. 76-81, September 2005. 